\title{
La sombra blanca de Casarás: génesis, fuentes y tradición de la ¿primera? novela fantástica sobre el Temple en España*
}

\author{
La sombra blanca de Casarás: Genesis, Sources and \\ Tradition of the First? Spanish Fantasy Novel about the \\ Knights Templar
}

\author{
Antonio Huertas Morales \\ Universidad Rey Juan Carlos \\ antonio.huertas@urjc.es
}

ORCID iD: https://orcid.org/0000-0002-2835-9088

\section{RESUMEN}

Hasta la fecha, La sombra blanca de Casarás, de Jesús de Aragón y Soldado, publicada por primera vez en 1931, había llamado la atención de la crítica sobre todo por la labor de su autor en la composición de La torre de los siete jorobados, con la que mantiene una evidente deuda. Las presentes páginas pretenden constituirse como el primer estudio dedicado exclusivamente a la obra y, a través del análisis de la presencia de la Orden del Temple en la misma, demostrar que, aun tomando elementos de Emilio Carrère, Jesús de Aragón escribió la primera novela española fantástica sobre los conmilitones Christi, originalidad especialmente relevante por el signo diabólico que adquieren sus magos-soldados.

Palabras Clave: Jesús de Aragón; La sombra blanca de Casarás; Emilio Carrère; La torre de los siete jorobados; Orden del Temple; Edad Media; novela gótica.

\section{ABSTRACT}

To date, La sombra blanca de Casarás, by Jesús de Aragón y Soldado, first published in 1931, had drawn the attention of the critic specially because of the work of its author on the composition of La torre de los siete jorobados, which La sombra blanca de Casarás is obviously related. This article aims to be the first study devoted in full to the piece. I show, through the analysis of the presence of the Order of the Temple, that Jesus de Aragon wrote the first Spanish

* Este trabajo se ha realizado en el marco del Proyecto Parnaseo (Servidor Web de Literatura Española), referencia FFI2017-82588-P (AEI/FEDER, UE). 
fantastic novel about the conmilitones Christi. It is an especially relevant novelty because of the devilish sign that its magicians-soldiers acquire.

Key words: Jesús de Aragón; La sombra blanca de Casarás; Emilio Carrère; La torre de los siete jorobados; Templar Knights; Middle Ages; Gothic novel.

\section{INTRODUCCIÓN}

Jesús de Aragón (Valsaín, 18 de marzo de 1893 - Madrid, 19 de abril de 1973) $)^{1}$, graduado en Ingeniería de ferrocarriles por correspondencia, trabajó durante buena parte de su vida en Gas Madrid, del que llegó a ejercer como director financiero, y en el Centro Español de Estudios por Correspondencia, del que terminó siendo asesor de economía y profesor. Conocido como «el Julio Verne español», además de bajo el pseudónimo de Capitán Sirius o el anagrama J. de Nogara, su carrera literaria, vinculada a las editoriales V. H. Calleja, en la que sustituyó a El Coronel Ignotus (José de Elola), y Juventud, se desarrolló entre 1921 y 1934, fecha temprana a partir de la cual ya no publicó ninguna novela².

Aunque actualmente es considerado precursor de la novela de anticipación (Sainz Cidoncha 1976), y su nombre es referencia constante en los estudios sobre la novela popular (o su «prehistoria») de aventuras, ciencia ficción y fantástica de la España de posguerra (Boix 2000; Lara López 2000, Vázquez de Parga 2000, 13-17; Charlo 2013, 146-147; Eguidazu y Tarancón 2008, 352), los trabajos sobre su obra se limitan apenas a las escasas y reiterativas páginas introductorias que encabezan las ediciones de sus novelas -de ahí que haya quien no dude de que habría recibido un mayor reconocimiento si hubiera nacido en otro país (Uribe 1994b, 14; Lejárraga 1995, 5)-, hasta el punto de que solo una diatriba sobre la entidad y alcance de la participación del valsabinense en la composición de La torre de los siete jorobados, de Emilio Ca-

${ }^{1}$ Escasos son los datos biográficos de los que disponemos. Los que aparecen en el presente artículo se deben a los todavía imprescindibles trabajos de Augusto Uribe (1994a, 1994b y 2000). El último de ellos es la agrupación de dos artículos anteriores sobre José de Elola y Jesús de Aragón: Uribe, Augusto (1994). «Apuntes para la historia de la ciencia ficción española. El Coronel Ignotus». Bem 38: 8-15, y Uribe, Augusto (1995). «Apuntes para la historia de la ciencia ficción española. El Capitán Sirius». Bem 44: 6-14.

${ }^{2}$ La producción de Jesús de Aragón aparece sistematizada en Labrador y Sánchez (2002, 499-500), por lo que resulta superfluo reproducirla. Hasta donde llegan nuestros conocimientos, solo habría que sumar la nueva edición de La sombra por la que citamos, amén de otra elaborada a partir de la de Juventud (1995) y a cargo de Ediciones Populares El Laberinto de La Granja (2010). 
rrère ${ }^{3}$, ha servido para centrar la atención sobre La sombra blanca de Casarás (1931, reeditada en la colección Universal, editorial Juventud, en 1995), quizá la mejor de sus novelas.

El objeto de las presentes páginas no es añadir más tinta a este debate, por otra parte, ya solventemente cerrado por Labrador y Sánchez (2002 y 2004), sino, con motivo de la reedición de esta última, a cargo de la librería-editorial Ícaro ${ }^{4}$, en primer lugar, aportar un estudio sobre los aspectos más relevantes de la misma, como creemos que merece y nunca ha conocido hasta la fecha, y, en segundo lugar, analizar la presencia de la Orden del Temple en la novela, puesto que se trata de la primera novela española en clave fantástica sobre los pobres caballeros de Cristo, veta ampliamente explotada en la narrativa actual.

\section{A LA SOMBRA DE CARRÈRE}

Según una carta biográfica rescatada por Lejárraga ${ }^{5}$, fechada en 1933 y que recuerda acontecimientos acaecidos «hace unos diez años», Emilio Carrère le vendió a Manuel Palomeque, encargado de la editorial V. H. Calleja, una novela inacabada (que resultaría ser La torre). Ante la negativa de Carrère a terminarla, se le encomendó la labor a Jesús de Aragón. No es de extrañar que un escritor en ciernes realizara una concienzuda labor de lectura y emulación 6 :

${ }^{3}$ En el presente trabajo, todas las citas de La torre de los siete jorobados y La sombra blanca de Casarás (de aquí en adelante, La torre y La sombra) corresponden a las ediciones de Valdemar e Ícaro, respectivamente, compiladas en la bibliografía final.

${ }^{4}$ La reedición ha supuesto la elaboración de nuevos trabajos. Véanse, por ejemplo, Adrados, Ulises (2016). "Cabalgando con templarios por la sierra madrileña», Zenda (2409-2016), disponible en https://www.zendalibros.com/cabalgando-templarios-la-sierramadrilena/; Rodríguez Lafuente, Fernando (2014). «Jesús de Aragón, el Julio Verne español», ABC Cultural (11-01-2014), y la reseña a cargo de Martín Mayorga, Daniel (2014). «Jesús de Aragón, el Julio Verne español». Revista de Occidente 393: 150-154. El 17 de abril del 2018 tuvo lugar un homenaje a Jesús de Aragón en el Instituto de España (Madrid), en el que participaron, amén de algunos de sus familiares, Luis Alberto de Cuenca, Fernando R. Lafuente y Pedro García Barreno.

${ }^{5}$ La nota, que se conserva en los archivos de la editorial Juventud, fue redactada por Jesús de Aragón a petición de José Zendrera, su editor, y le fue enviada a Ángel Dotor para su artículo laudatorio sobre el primero. Véase Dotor, Ángel (1933). «Vida literaria y artística. El Julio Vernes (sic) español». Vida marroquí (24/12/1933), p. 9. Se reproduce íntegra y anotada en Palacios (2015). El episodio, además, lo relata o re-crea, más bien (según Labrador y Sánchez 2002), Cansinos Assens 1985, 13-19. Vale la pena mencionar también el testimonio de Antonio Ribera, que recuerda que los propios José M. ${ }^{a}$ y Pablo Zendrera le mostraron los contratos «por doscientas o trescientas pesetas la obra» para convencerlo de que Jesús de Aragón no era un pseudónimo. Véase Ribera 1984, 17-18.

${ }^{6}$ «Pedí la colección completa de sus obras y durante tres meses me dediqué con verdadero ahínco al estudio de su precioso estilo, de sus múltiples y geniales recursos literarios 
Palomeque y el propio Carrère quedaron satisfechos, y Jesús de Aragón vio publicadas sus dos primeras novelas.

Palacios $(2015,29-31)$ dio por buenas las fechas de la nota de Jesús de Aragón y, considerando que la primera edición de La torre se había publicado en 1924, entendía que el legajo entregado por Carrère era su obra Un crimen inverosímil (1922, número 324 de la colección La Novela Corta), además de páginas en blanco y algunas correspondientes a otras de sus obras. Trazó así un cuadro para desentrañar qué parte de La torre era de cada autor, en el que determinaba que más de la mitad de la obra se debía a la pluma de Jesús de Aragón ${ }^{7}$. Sin embargo, Palacios equivocaba la base de sus planteamientos, ya que, como más tarde demostrarían Labrador y Sánchez (2002), las dos primeras ediciones de la novela de Carrère ya estaban publicadas en 1920. Posteriormente, ambos estudiosos (2004) desvelaron que La torre había aparecido en forma de folletón en el periódico La Nación de Madrid en treinta y tres entregas entre el 8 de septiembre y el 7 de noviembre de 1918. Se trata de los dieciséis primeros capítulos, es decir, toda la primera parte de la posterior novela, con el mismo título y texto que tendrían en la edición definitiva. Siendo así, la tesis de Palacios quedaba totalmente refutada y el papel de Jesús de Aragón se veía limitado a «por un lado incrementar mediante intercalación de textos el original de la novela dándole la dimensión requerida con la redacción parcial de la segunda parte y, por otro poner orden en un totum revolutum no tan desestructurado como a primera vista pudiera parecer» (Labrador y Sánchez 2004, 931).

Las concomitancias entre ambas novelas son notables y han sido siempre señaladas por los críticos. Uribe $(2000,51)$ afirmaba que «No cabe discusión. El final de La torre de los siete jorobados coincide con el de La sombra blanca de Casarás, de Jesús de Aragón, de una forma tal que tienen que haber salido de la misma pluma», mientras que Palacios $(2015,34)$ hablaba de «remake rural»».

Si Labrador y Sánchez $(2002,493)$ pensaban que Aragón había intervenido en cuatro capítulos $(10,12,13$ con reservas y 16) de La torre, tras su trabajo posterior (2004) queda claro que son de Carrère, por lo que Jesús de Aragón -sin descartar, obviamente, otras influencias y sin poder discernir qué copió

\footnotetext{
y a desentrañar el enigma de su pensamiento, para saber por qué derroteros hubiera conducido la trama de su obra» (Palacios 2015, 23).

${ }^{7}$ La datación errónea de La torre y el papel de Jesús de Aragón en la composición de la misma se mantendrán en estudios posteriores, si bien el propio Palacios ya tuvo en cuenta las nuevas aportaciones en la edición, para Valdemar, de La calavera de Atahualpa y otros relatos (2004). Véanse, al respecto, Aguilar 2002 y Méndez 2002. También se habla de autoría compartida y se remite al prólogo de Palacios en Gregori 2017, mientras que Fioraso y Fioraso $(2007,235)$ se refieren a La torre como «scritto da Aragón ma uscito con il nome di Carrere».
} 
conscientemente y qué había interiorizado a lo largo de las lecturas que le permitieron empaparse del estilo de Carrère-, tomó prestados caracteres y situaciones.

El Basilio Beltrán que protagoniza La torre es «un médium, esto es, una sensibilidad hiperestesiada, capaz de percibir las formas fluídicas» (63), del mismo modo que la Graciela de La sombra es «uno de esos seres fácilmente influenciables que la ciencia conoce como sujetos favorables para sus pruebas hipnóticas y los espiritistas, algo más avanzados en sus experimentos, califican de un buen médium» (56); el doctor Robinsón desdeña en La torre el vaticinio de su muerte porque "como médico era materialista y no hice caso. Me reía de augurios, de sueños proféticos y de poderes sobrenaturales. Todas esas cosas me parecían cuentos de aldeas» (63), mientras que don Mariano, el médico de Valsaín en La sombra, «como hombre dado a los estudios de ciencias puramente humanas, era un poco materialista» (29); Ercole es, en La torre, un autómata que «anda como un muñeco movido por un resorte, igual que andaba el muchacho misterioso, flaco y amarillo y mal vestido que perseguía al señor Catafalco dos meses antes de ser asesinado» (146), en tanto que Bisol y los caballeros de Hugo de Marignac, según relata Graciela en La sombra, "Son verdaderas máquinas humanas, cuerpos sin voluntad y hasta sin alma racional me atrevería a decir, que se mueven al influjo de una voluntad que les transmite su mecánica existencia» (157); el ritual de Sabatini (281), ya empleado por Carrère en «Embrujamiento» ${ }^{8}$, lo aprovecha Jesús de Aragón para que, gracias a Oriel, Hugo de Marignac pueda rendir a Blanca de Torreñuno; el excéntrico arqueólogo Sindulfo del Arco de La torre, «en el fondo un doncel romántico, digno de ser cantado por Walter Scott» (184) y trasunto de Valle-Inclán, según Labrador y Sánchez $(2002,482)$, le sirvió a Jesús de Aragón para la creación del geólogo Franz von Kunzel, miembro del Instituto Geológico de Berlín (al que también Jesús de Aragón describe como arqueólogo [139]): tan obsesionado está el primero con encontrar la sinagoga subterránea de Bel-Luzbel como el segundo por hallar la cierva de Sertorio, ambos se ausentan cuando los personajes son perseguidos, colaboran a cambio de ayuda que les permita seguir con sus pesquisas y acaban siendo asesinados.

Averiguado qué toma La sombra de Carrère, queda por ver qué le debe $L a$ torre al de Valsaín, considerando que los añadidos Jesús de Aragón a La torre tienen que ser, forzosamente, de la segunda y tercera partes, algunos de ellos reciclados en La sombra. Según Labrador y Sánchez (2002), los fragmentos donde se nota la huella de Jesús de Aragón son el 17 (el de Valsaín únicamente mete algo de pluma), 19 y 20 casi en su totalidad, el 21, algunos intercalados del 23, 24 y 25, y también algún añadido mínimamente significativo de la tercera parte. Debemos ser, no obstante, precavidos, ya que en ocasiones se basan en

${ }^{8}$ En Almas, brujas y espectros grotescos. Madrid: Sanz Calleja, 1919. 
criterios estilísticos y conceptuales que pueden quedar en entredicho, pues, como se ha expuesto más arriba, juzgaban como propios de Jesús de Aragón fragmentos que luego (2004) se demostraron de Carrère. Los elementos que Jesús de Aragón incluyó en La Torre, y que luego aprovecharía o desarrollaría en La sombra deben de ser los más aventurescos -al menos, una amplificatio, no en vano se demuestra ducho en la concatenación de peripecias en sus novelas- y los que tienen que ver con el mazdeísmo9. Sindulfo del Arco es un «morgbedo» iniciado en Oriente, cuyos poderes y conocimientos no pueden competir con los de Sabatini, un maestro «desturmorgbedo» en La torre, mientras que el Oriel (nótese la similitud con Orifiel) de La sombra tiene también «espíritu de desturmogvedo persa, transmitido por los magos de Oriente» (106); la canción entonada por los jorobados en las galerías del Madrid subterráneo dice «Ormuzd, Ormuzd, rey inmortal. / Dios de la luz, como Luzbel / manda a tu arcángel Orifiel / sobre este lecho sepulcral» (195), mientras que en la extraña liturgia conducida por Sabatini se invoca a Arimanes (211), del mismo modo que Marignac exhorta a bafomet, que lee «en el libro de Ormuz», y en el altar de la divinidad del mazdeísmo debe ser sacrificada una doncella o un inocente para devolverle la vida a Marignac en La sombra. Finalmente, ambas novelas concluyen tras una persecución (enmascarados en La torre, encapuchados en La sombra) por galerías subterráneas que comparten precipicio y cenagal, y un prosaico final, en manos de las autoridades, que se impone a la maravilla.

La sombra es una novela singular en la producción de Jesús de Aragón, aunque la búsqueda del tesoro maldito, la irrupción del pasado, las persecuciones por el subsuelo, etc., se encuentran presentes también en La ciudad sepultada. Que Jesús de Aragón la concibiera durante sus lecturas de Carrère -el del relato fantástico, la crónica y las leyendas- nos parece irrefutable ${ }^{10}$. Bien podría haberse inspirado en El diablo de los ojos verdes (La Novela de Hoy, 1922), donde se menciona «el reino del macho cabrío, del negro arcángel protervo, del Baphomet de los templarios nigromantes perseguidos por la Iglesia» (2010, 26) o en otras narraciones como La conversión de Florestán (1921), en la que el novelista homónimo, «en excelentes relaciones con todos los espiritistas, cartománticos, quirománticos, saludadores, astrólogos y magnetistas de todo Madrid» (10) e incapaz de sustraerse a la pasión hacia miss Angélica, discípula de Blawatsky, participa en una misa negra, de la mano de la Orden de los tenebrarios, para acabar yaciendo con una joven que, como determinará el forense, lleva tiempo muerta ${ }^{11}$.

${ }^{9}$ En La torre se incluyen más detalles, pero no una mayor claridad: se hace referencia a Zurvan y el retiro de Zoroastro al monte Albordi, donde Ormuzd le dictó los Naskas (197). También se mencionan, como en La sombra, los Vedas (261).

${ }^{10}$ Para Carrère y el gótico, véase Aldana Reyes 2017, 141-147.

${ }^{11}$ Sin embargo, sería imprudente descartar que el interés de Jesús de Aragón por la masonería viniera de lejos, si tenemos en cuenta que llegó a escribir una novela al respecto, 
Jesús de Aragón no ponía gran empeño en la datación de sus obras, pero, cuando lo hace, estas son contemporáneas a su publicación y, debemos pensar, a su escritura, hasta el punto de que sus reediciones aparecen actualizadas (Uribe 1994a, 13). Entre Cuarenta mil kilómetros a bordo del aeroplano «Fantasma» (1921) y Los piratas del aire (1929) pasan ocho años en los que, publicara más o menos en el extranjero (Francia y Hungría), nuestro autor siguió escribiendo, puesto que «La facilidad con que Aragón entrega tres obras a Juventud, que ésta publica una a continuación de la otra en el lapso de muy pocos meses, hace pensar que se trataba de obras preparadas con anterioridad y que el autor no había podido publicar» (Uribe 1994b, 7). Es posible que de esa época date también La sombra. En la nota rescatada por Lejárraga, Jesús de Aragón «recuerda» estar completando La torre unos diez años antes, es decir, en 1923. En La sombra hay una fecha relevante, 1893, año del nacimiento de nuestro autor, pero también fecha la que el marqués de Aspromonte viaja a España, se hospeda en casa de don Andrés y desaparecen las estatuas de Hugo de Marignac y la condesa Blanca. El relato de don Andrés se sitúa unos treinta años más tarde, es decir, hacia 1923. Esta coincidencia, aunque podría ser solo mera anécdota, nos plantea la duda razonable de si Jesús de Aragón ese año de 1923 no estaba trabajando en La torre sino en La sombra, obra que empezó tras haberse familiarizado con el estilo de Carrère y que solo acabó o publicó más tarde. Quizá su memoria no resulte errónea en la cronología, sino en la obra que se traía entre manos: quizá creía completar La torre, pero escribía La sombra.

El carácter de «borrador», de manuscrito inacabado o guardado en el cajón vendría a explicar los desajustes cronológicos que nos han disuadido de estructurar la síntesis en bloques temporales, puesto que la ligereza en la reconstrucción del pasado medieval va acompañada de cierta dejadez en la coherencia interna, especialmente por lo que se refiere a la falta de cierre de la misma (si bien la inconcreción deriva en poderoso acicate imaginativo): el primer narrador es Gabriel, pero quien acaba la novela dirigiéndose como testigo, no a al resto de los personajes, sino a los lectores, es don Andrés ${ }^{12}$.

Enrique, cuyo protagonista tenía rasgos de un familiar (Lejárraga 1995, 15; Uribe 2000, 52). Por no molestarlo, quedó inédita, aunque podría ser ampliamente reveladora sobre los conocimientos de Jesús de Aragón.

${ }_{12}$ Por lo demás, la narración de don Andrés tiene lugar «hace unos treinta años, precisamente a raíz de mi regreso al pueblo, cuando terminé mis estudios en el seminario» (30). El párroco repite dos veces más que treinta años antes $(31,35)$ ya los lugareños le hablaban de las apariciones. Sin embargo, más adelante, al hablarnos de la llegada del marqués de Aspromonte, que el caballero Rizzi recuerda en 1893, nos dice que se produjo «a los pocos años de haber venido a Valsaín, casi recién salido del seminario», momento claramente anterior a sus primeros recuerdos. Sin embargo, afirma que de entonces «datan las primeras apariciones del monje blanco por el valle, y fue entonces cuando me trajeron las primeras noticias los gabarreros, hablándome también del notable parecido que tenía el fantasma con 


\section{LA SOMBRA BLANCA DE CASARÁS}

En la novela, Gabriel, primer narrador y alter ego de Jesús de Aragón ${ }^{13}$, presenta el paisaje de su juventud (Valsaín, La Granja, La Pradera), con las ruinas del monasterio de Casarás, y a los otros personajes del pueblo (el párroco don Andrés; don Mariano, el médico; don Francisco, practicante y barbero; Domiciano, sacristán y factótum). Sus recuerdos se remontan a una noche de junio en la que su hermano Emilio, que llegaba a Valsaín procedente de Madrid, emprende el camino en solitario desde Cercedilla debido a un descarrilamiento. Para alegría de todos, Gabriel llega al pueblo, y narra la que será la primera aparición del templario Hugo de Marignac:

-[...] un jinete blanco vistiendo una capa blanca que flotaba al viento a impulsos de la desenfrenada carrera, llevando además bordada sobre el lado del pecho una cruz roja ochavada que parecía de fuego.

$[\ldots]$

-¡Hugo de Marignac! -exclamó el señor Francisco, cambiando una mirada de inteligencia con don Andrés.

-Con todo -prosiguió Emilio-, esta aparición tan extraña y tan extemporánea no me hubiera llamado la atención a no ser por el color negro que tenía la cara del jinete, sus facciones descarnadas y huesosas y los grandes alvéolos que formaban las órbitas de sus ojos vacíos, verdaderos ojos de esqueleto, pero sobre todas estas cosas, por un nombre extraño que pronunció a mi lado, seguido de una imprecación que no pude entender.

- ¿Y cuál fue ese nombre? - preguntó don Andrés con manifiesta curiosidad.

- ¡Bafonet! -prosiguió Emilio-. Creo que invocaba a Bafonet como una divinidad protectora. Sin embargo, no pude comprobar estos detalles, porque cuando la luz de un nuevo relámpago me permitió verle otra vez, ya el terrible jinete había pasado como una exhalación por el camino, levantando un reguero de chispas al chocar con los cascos del caballo contra las piedras de la calzada. Después continué viéndole aún en medio de las tinieblas con su airosa capa blanca como

la estatua del parque» (42). La cronología de Graciela es también muestra de esta poca atención al detalle: el marqués de Aspromonte, según recuerda Rizzi, viaja a España en 1893, regresa a Italia con su supuesto pariente, Hugo de Marignac, y debieron de desposarse de manera rápida, ya que entre la petición y el matrimonio solo transcurren dos meses (63). La misma noche parten hacia España. Rizzi, enterado de cómo vive su hermana, llega a Madrid, pero al preguntar por la pareja, le informan de que hace tres meses que ya no viven en su casa de la calle Luzón (64), y cinco meses que el peatón recibe las cartas de Hugo de Marignac (66). No ha podido pasar, por tanto, tanto tiempo como para que don Antonio -dentro del relato de don Andrés- afirme que esas cosas no eran propias del siglo XX. Lo mismo se puede decir del plazo dado por el grupo de don Andrés para recibir socorro, que pasa de cinco días a la policía de Segovia (172) a tres días a la Guardia Civil (182).

${ }^{13}$ Uribe $(2000,62)$ y Lejárraga $(1995)$ dan cuenta de los detalles que emparentan al narrador y al escritor: su padre, Marcos, es director de la fábrica de madera Pradera de Navalhorno, su esposa se llama Lola (también es el título de la primera novela de Jesús de Aragón, hoy perdida y con una interesante vida editorial), tiene cuatro hijos, etc. 
dotado de luz, corriendo ingrávido, vertiginoso, por el borde mismo de aquellos precipicios (18-19).

Los rigores de la tormenta obligan a Gabriel a buscar refugio en Casarás, pero unos alaridos le impiden el descanso y, decidido a averiguar su procedencia, ve a «cinco o seis hombres cubiertos con ropajes blancos inclinados alrededor de una gran mesa de piedra que existía en el centro» (22) a los que no llega a alcanzar. Cuando, tras vagar por el monasterio, logra encontrar la salida, se encuentra con una nueva aparición, que introduce al lector frente a la dualidad (¿el doble astral tan del gusto de Carrère?) del templario:

-... No era un ser fantasmal como debería serlo el personaje aquel con quien hube de tropezar a mi llegada, sino, al contrario, parecía un hombre dotado de una exuberante vida y energía.

Su larga barba blanca y su chaqueta de irreprochable corte, completada por su pantalón de jinete y por unas botas altas reforzadas por lustrosas polainas de cuero, daban a conocer en él al hombre distinguido, hecho a toda clase de deportes y aficionado a los placeres, un tanto emocionantes, de la equitación por aquellos empinados caminos de la sierra ... (26).

El relato de Emilio da lugar a lo que será una constante en la novela: la discusión entre la realidad o ficción de la aparición, donde se impone la voz de don Andrés, que se dispone a relatar lo vivido treinta años antes. Llegado a Valsaín tras su paso por el seminario, se encontró con un pueblo atemorizado por siniestras apariciones. Con la intención de acabar con ellas, se encaminó con don Antonio, el médico en aquella época, hacia las ruinas de Casarás, pero interrumpieron su expedición al ver una luz en la torre del palacio (recuerda entonces don Andrés una mala experiencia habida cuando niño con la estatua de Hugo de Marignac, sorprendentemente parecido al marqués de Aspromonte, aristócrata italiano llegado a Valsaín que aceptó la hospitalidad del párroco y tras cuya llegada se produjeron misteriosos sucesos, como la desaparición de las estatuas de Hugo de Marignac y Blanca de Torreñuno). Al regresar al palacio para examinar aquel resplandor, se encontraron con una mujer herida que huía perseguida por varias sombras blancas y a la que no pudieron salvar de la muerte. El estudio de un manuscrito con la crónica del monasterio de Casarás al que se dedicó posteriormente don Andrés coincide con la llegada del señor Rizzi, comerciante de Reggio Calabria y hermano de la joven muerta, Graciela, esposa de Hugo de Marignac, además de artista de ópera y médium. Relata Rizzi que llegó al castillo de Aspromonte el supuesto descendiente de Marignac o el espectro de su antepasado templario. El marqués marchó a España (momento de encuentro con don Andrés, 1893, según la memoria de Rizzi) y regresó con el que dice ser su pariente, Hugo de Marignac, con el que mantiene un asombroso parecido, «... con la diferencia de que mientras el marqués parecía una sombra, un ser ya caduco y agotado, el otro, alto, fornido, de arro- 
gante presencia, en todo el desarrollo de una potente virilidad, parecía el hermano menor» (61). El recién llegado cortejó a Graciela y la pidió en matrimonio. Un matrimonio que, ella era consciente, supondría su desgracia, pues su marido, que no puede ser otro que un espectro, amaba solo al fantasma de Blanca de Torrenuño. El intento de reconocer el cadáver de Graciela resultó infructuoso, pues desapareció, como la voluntad de los hombres del pueblo por desenmascarar a los culpables e investigar el monasterio de Casarás tras una amenazadora nota de quien firma como La Sombra del Monasterio de Casarás.

Sigue la narración con la historia del Temple y el imaginado pasado medieval de Valsaín, donde llegó Hugo de Marignac con una pequeña comitiva y cuatro voluminosos carros para cumplir una misión de la Orden cuando empezó su persecución en Francia. Pronto dio lugar el templario a las habladurías, puesto que su trato despótico y sus misteriosos viajes con freires y braceros de los que nunca más se supo coinciden con gritos en la Ventana del Diablo. Marignac consiguió atraer a los más disolutos de entre los templarios castellanos y por el lugar empezaron los raptos y desapariciones. Sin embargo, su peor acción tuvo lugar hallándose Sancho IV y María de Molina en el palacio de Valsaín, donde el rey no quería proceder contra la Orden y la reina la defendió, también porque en aquella época don Pascual, abad de Valladolid, llegó con una embajada de la corte de Felipe IV: quería que el papa anulara el matrimonio de los monarcas para que Sancho IV pudiera casarse con una princesa de Francia. Marignac quiso seducir a Blanca de Torreñuno, que tenía su boda ya concertada con Roger de Alenza. Pero ni eso «ni sus propios votos eran, no obstante, obstáculo que pudiera detener la violenta pasión contraída por el caballero de Marignac» (97): don Pascual y el joven acabaron convertidos en estatuas para adornar el pasaje del palacio de los reyes. Para rendir a la dama, Marignac acudió al mago Oriel, a quien traicionó y dio muerte, y la secuestró, si bien, hostigado por los guardias, se despeñó con ella por la Ventana del Diablo y la reina doña María recibió para el paseo del palacio las esculturas de la condesa Blanca y del templario Hugo.

Acaba así el relato medieval del manuscrito y don Andrés retoma el hilo de sus vivencias: todo estaba olvidado desde las amenazas hasta que un día un hombre se intentó suicidar en la fábrica de madera de La Pradera. Cuando lo visitó para darle la extremaunción, el herido se presentó como Franz von Kunzel, miembro del Instituto Geológico de Berlín, y les reveló que la mujer que murió en el pueblo era necesaria para que Hugo de Marignac la sacrificara a Azrael y volver así a la vida en su propio cuerpo, y que las estatuas del palacio eran cadáveres sobre los que actuaban manantiales petrificadores, algo que Marignac debió de aprender en Oriente. En realidad, el alemán no sabe si es Marignac, o Aspromonte, o los dos, pero sí que el espectro estaba interesado en aprovechar sus dotes de hidromántico para volver a la vida su cadáver y desenterrar el tesoro del Temple. Antes de despeñarse con Blanca de Torrenuño por la Ventana del Diablo durante la Edad Media, el templario dejó escrito 
un texto que nos resulta revelador de su maldad y del porqué de la persecución contra la Orden: sí hubo un grupo de licenciosos templarios que supo «humillar en París el orgullo de una reina poderosa» (147) y embruteció incluso a las princesas Blanca y Margarita de Borgoña ${ }^{14}$. Felipe IV aprovechó la ocasión para atacar a la Orden, pero Jacques de Molay, aunque inocente, los mandó a España para que ocultaran el tesoro de la Orden y para que su prisión no provocara males mayores.

Por su parte, Von Kunzel se negó a participar en sacrificio alguno e intentó huir con Gabriela, pero la fuga fracasó y quiso suicidarse en la fábrica de madera y evitar buscarles una nueva víctima. Para desvelar de una vez la verdad, don Andrés y los suyos van hasta Casarás, pero sin el alemán, que ha desaparecido del pueblo con dos trabajadores de mala reputación. Dispuestos a pasar la noche en las ruinas, son capturados, pero Von Kunzel, obsesionado con la cierva, acaba rescatando a don Andrés, que por boca del geólogo descubre que sus compañeros están siendo petrificados.

Al intentar liberarlos, son testigos del ritual en el que el espíritu y el cuerpo de Hugo de Marignac se encuentran:

Sobre el altar donde la Sombra se debatía en contorsiones desesperadas acababa de aparecer un gato negro, cuyos ojos dorados parecían clavarse en los del templario.

-¡Bafonet! -gritaba este, aumentando su furor hasta echar espumarajos por la boca-. Genio de los espíritus del mal. ¡Haz el milagro!

Las miradas del gato se pasearon por la sala con sospechosa curiosidad y después, levantándose sobre las patas traseras, se quedó clavado en aquella postura, mirando fijamente al cadáver de Marignac. Automáticamente y como obedeciendo a un poder irresistible, la sombra se volvió al cadáver. Los encapuchados se habían retirado, dejándole solo en medio de la estancia.

-Es el diablo -murmuré al oído de mi acompañante-. Este poder de hacer que acudiera en forma de gato negro es el que se atribuía a los templarios cuando los procesó Felipe IV de Francia, aparte de otras muchas monstruosidades.

-Escuche usted -volvió a decirme el geólogo, imponiéndome silencio.

El mago había vuelto a ponerse en movimiento y, con la vista fija en el cadáver, dio dos vueltas alrededor del mismo sin perder tampoco de vista al siniestro gato.

De pronto se detuvo y gritó estas palabras:

-Hugo de Marignac, servidor de Arimanes, espíritu infernal que supiste sustraer el tesoro de la orden a la codicia de los mortales, levántate y escucha lo que dice Bafonet.

Entonces ocurrió algo increíble, que lo mismo podía ser un caso de ilusionismo teatral que extraordinario prodigio. La Sombra se inclinó sobre la caja y lentamente fue desapareciendo como absorbida por el cadáver. Oyóse a continuación un ruido extraño como de huesos que chocan entre sí; inmediatamente la cara del

\footnotetext{
${ }^{14}$ Alude aquí Jesús de Aragón a los acontecimientos de la Torre de Nesle que quizá conocía en la edición Calleja (La novela de Ahora) para la obra de Michel Zévaco.
} 
cadáver se coloreó y fue adquiriendo una apariencia de vida, como si la sangre empezase a circular por sus apergaminadas venas.

Sin embargo, aparece Blanca, que le ofrece su amor si renuncia a su anterior vida depravada. Marignac acepta, pero la policía y las balas acaban con el reencuentro. Y con lo extraordinario del relato: si hubo tesoro, uno de los villanos contratados por Von Kunzel se lo llevó, y si La Sombra se entregó a la policía, en la cárcel solo quedará un cadáver. La autopsia revela que lleva siglos momificado.

\section{De nuevo, la Edad Media}

Jesús de Aragón recupera la Edad Media en un momento en que, tras el auge del siglo anterior, había perdido interés y relevancia, pero sin llegar nunca a desaparecer ${ }^{15}$. La novela histórica de origen romántico, que había dado lugar, siguiendo la clásica división de Ferreras (1976), a la novela histórica de aventuras, la novela de aventuras históricas y a los grandes folletines en la segunda mitad del siglo XIX -y cedido su protagonismo a otros ambientes y períodos-, ya en la primera mitad del siglo XX aparece en colecciones para jóvenes, mutilada o adaptada. No obstante, la historia medieval -basta con pensar en el caso del Cid «el de la barba bellida, el de la fiera tizona, el de las grandes hazañas, el insigne Caballero, dechado españolísimo de valor y prudencia, de lealtad y justicia, de pulcritud y sencillez ...» (León 1942, 238)seguía bien presente en los proyectos regeneracionistas o simbólico-esteticistas tanto de noventayochistas como de modernistas y vanguardistas, incluso en pastiches del «modernismo castizo» (Ara Torralba 1996) en los que San Francisco o el marqués de Santillana desfilan en la danza de la muerte soñada por Jesús de Ceballos en Casta de hidalgos (1914), de Ricardo León, o en la lúdica y desquiciada superhistoria de Gómez de la Serna, con espacio para la reina Urraca, los siete infantes de Lara o Juana la Beltraneja ${ }^{16}$.

Jesús de Aragón retoma acciones, caracteres y el andamiaje escenográfico de la novela gótica, con motivos también recurrentes en la novela histórica ${ }^{17}$, tales como las apariciones, la presencia de nigromantes y alquimistas, el gusto por las ruinas, las persecuciones a través de laberínticos subterráneos, las pasiones materializadas

15 Hasta donde llegan nuestros conocimientos, aparte de las leyendas Bécquer (El monte de las ánimas y El rayo de luna [1862]) y de Blasco Ibáñez (La espada del templario [1887]), ninguna novela sobre la Orden del Temple se publicó en nuestro país entre 18561857 (Los templarios, de Juan de Dios de Mora) y 1950 (Rafael Pérez y Pérez: El templario. Barcelona: Juventud).

16 Tres de los relatos o novelas cortas que forman el volumen de Gómez de la Serna (1944)

17 Véanse al respecto Almela 2006 y Mata 1995. 
en abusos por parte del villano, las intervenciones demoníacas más o menos explicadas o explicables, las fuerzas desatadas de la naturaleza, los crímenes violentos (Álvarez 1998, 69-71). Ya el mismo inicio de la novela, con Gabriel buscando refugio en mitad de la tormenta en las ruinas del monasterio, nos remite al Eugenio que vaga por las orillas del lago Benaco y que acaba encontrándose con la presunta sílfide (Pérez y Rodríguez 2010), o a la llegada de Adolfo y su escudero Astolfo a las ruinas de Munsterhall (Pérez y Rodríguez 1833). Hugo de Marignac es un seductor a lo diabólico como, solo por continuar con Pérez y Rodríguez, Alberto (1833) o Ambrosio Scianella, con el que comparte también el carácter de pervertidor (2010), de la misma manera que Blanca de Torreñuno, dispuesta a redimir a Hugo de Marignac, parece mirarse en la Lucrecia de esta última.

Jesús de Aragón transforma en clave fantástica los parajes de su infancia, rehuyendo el común exotismo de la ambientación, del que apenas queda la referencia a esa Italia (Aspromonte, Reggio Calabria) tan cara a la narrativa gótica. La sombra es, ante todo, un homenaje a la geografía donde nació en autor, de ahí que en las descripciones aproveche para dejar bien trazados los puntos más genuinos (el cerro de Matabueyes, el arroyo de Dos Hermanas, el arroyo de la Reina, la boca del Asno, la fuente del Pájaro, los Siete Picos, el Cerro Pelado, la Fuente de la Reina, el pico del Viento). Algunos de estos espacios tienen su propia leyenda (el Montón de Trigo) y a algunas leyendas se les dará un nuevo origen (la ventana del Diablo, desde donde se precipita Hugo de Marignac con Blanca de Torrenuño - caída y abismo de claro simbolismo en el satánico templario que quiebra sus votos-y donde se oculta el tesoro; la Cueva de Monje, refugio de Oriel, enclave preñado de connotaciones míticas y literarias que van desde Hércules hasta el marqués de Villena), pero el armazón narrativo recae en una leyenda de la zona sobre los amores truncados de un caballero y una dama de la corte real que mantenían sus encuentros en el puerto de la Fuenfría y que quedaría trasformada a partir de la novela de Jesús de Aragón, incluyendo ya para la posteridad la huella templaria, de la que no había constancia anteriormente (Monterrubio 2013, 6; Lejárraga 1995, 16-17) ${ }^{18}$.

Encontramos, por tanto, el conflicto entre la razón y lo sobrenatural, fundamental en el género gótico y en su configuración y adaptación a la novela española en el siglo XIX ${ }^{19}$, caracterizada por «la búsqueda incesante de la verosimilitud literaria y del realismo más palmario» (López Santos 2010, 16). Baste recordar el prólogo de Pérez y Rodríguez a su novela La torre gótica o el espectro de Limberg:

Hemos procurado observar la mayor verosimilitud posible en los lances al parecer sobrenaturales y prodigiosos sin recurrir en el desenlace a agente extraordinario

\footnotetext{
18 Así la incorpora, por ejemplo, Enríquez de Salamanca 1981, 185.

19 Sobre el gótico en España, remito a López Santos 2010. Sobre la tipología, existe un resumen en Molina Foix 2008, 18-19.
} 
ni a potencia milagrosa. Desvanece todo el prestigio y placer del lector una narración inverosímil o un personaje sin relación con los que figuran en la historia, creado únicamente por la caprichosa fantasía del escritor (1831, IX-X).

Sin embargo, en esta dialéctica entre razón y fe, Jesús de Aragón sí deja lugar a lo fantástico. La razón y el positivismo corresponden a don Antonio y don Mariano, los hombres de ciencia, mientras que la credulidad y la fe, a don Andrés y Domiciano, hombres de Iglesia. La posibilidad de la existencia real de Hugo de Marignac es una duda continuada entre los protagonistas, que vacilan entre creer o atribuir las apariciones al elaborado plan de unos malvados, esa «vacilación» que es clave en la definición clásica de lo fantástico de Todorov $(2001,56)$. La pregunta inicial que hace Emilio, «-¿Me creerán ustedes si les digo que he visto una aparición en las ruinas?» (18), no deja de repetirse $^{20}$. Mientras que don Mariano se niega a creer, don Andrés afirma haberlo visto también, así como otras personas del valle y don Francisco. En realidad, tres son los relatos principales puestos en tela de juicio ${ }^{21}$ : el de Gabriel, el de don Andrés y el del propio alemán, que tras su intento de suicidio parece trastornado (aunque ya se mostraba así buscando a la cierva de Sertorio):

-Loco rematado -dijo don Antonio cuando se alejó-. Este hombre ha debido de contarnos una endiablada historia en la que puede que no haya nada de cierto.

- Algo sí que habrá -me respondió el doctor-, porque hay ciertos detalles que coinciden por completo con nuestras noticias. Con todo, creo también que su historia debe de ser una mezcla de verdades y mentiras urdidas y amasadas por su imaginación enferma (169).

Antonio luego vuelve a reírse cuando se menciona a los espíritus (169), y cree que lo que pasa en el valle es cosa de bandidos (171), a los que pretende dar caza son sus armas (174), tan intrépido como pudieran serlo Múller y Palotski (Pérez y Rodríguez, 1831). Puede conceder que si algo pasó fue en la Edad Media, pero hasta la leyenda quiere deshacer a fuerza de razón (176) y anima a sus acompañantes a pasar la noche en las ruinas de Casarás. Él dor-

${ }^{20}$ De nuevo les pregunta Emilio si creen que ha sido una alucinación (29), y cuando don Andrés se dispone a contar su historia, don Mariano, riendo, pregunta si es «un cuento de fantasmas» (30), a lo que don Andrés responde diciendo que lo que se predispone a contar es bien cierto. Ya él mismo había pensado que las visiones de los lugareños se debían a la «autosugestión» (37), frente a su «incredulidad sobre tales apariciones» (38). Finalizado lo expuesto en la crónica «no todos los que escuchaban aquella alucinante historia se dejaban influir del mismo modo. Entre los presentes había espíritus escépticos que no admitían con facilidad leyendas en las que lo sobrenatural se mezclara con los sucesos ordinarios de la vida, tradiciones creadas, según ellos, por las creencias supersticiosas de la época» (129). Don Mariano será, de nuevo, uno de estos.

${ }^{21}$ Pero no los únicos: Von Kunzel, por ejemplo, empieza también albergando dudas de lo que le narran La Sombra y Graciela. 
mirá tranquilo, pero no así Domiciano, supersticioso. Sin embargo, acabada la peripecia, con un dolor en las piernas bien real (202) y viendo al resto de amigos desmayados, la seguridad de Antonio se tambalea.

También don Andrés dudará, pero le resulta inútil negar la evidencia (191), y al final deja al lector la responsabilidad de elegir: «¿Fue un sueño o realidad esta última parte de nuestras extraordinarias aventuras? Cosas son estas que no me será posible asegurar jamás, a pesar de que conservo aún sus episodios en mi imaginación con la misma nitidez que se conservan los sucesos vividos» (203); que se volverá a reiterar: «Juzgue el lector como quiera; para nosotros, testigos presenciales del hecho, aquello continúa siendo un misterio» (208). Cierto es que nada queda del tesoro, pero esta vez la ciencia misma es la que responde: aunque Antonio vuelve a atribuir los crímenes y apariciones a un «mixtificador que se aprovechó de la leyenda», la autopsia revela que Hugo de Marignac, o La Sombra, lleva siglos momificado. Quedará la duda de por qué, treinta años después, ha regresado.

Por otra parte, la documentación de Jesús Aragón ha sido objeto de distintas valoraciones. Mientras que para Labrador y Sánchez (2002, 495-496) el novelista se limitó a reproducir las acusaciones históricas a los Caballeros Templarios tomando como fuente el Diccionario Espasa y demostrando, comparado con Carrère, escasos conocimientos en cultura satánica, para Lejárraga (1995, 16), sin embargo, «Es evidente que Jesús de Aragón se documentó ampliamente sobre la historia de las cruzadas y que conocía las obras de Walter Scott, muy difundidas en la época. Asimismo, no es aventurado pensar que había leído El señor de Bembibre, de Enrique Gil y Carrasco».

Al respecto, consideramos que no tiene sentido atribuirle a Jesús de Aragón voluntad historicista alguna: como las novelas góticas que preludiaron el advenimiento de la novela histórica, fijando un marco cronológico pseudohistórico (Álvarez 1998, 72), en La sombra no hay que buscar un rigor no pretendido. Para Jesús de Aragón la ambientación medieval es solo un recurso y la precisión de los datos algo prescindible. En ello coincidimos con Uribe (1994a, 11, 15): Jesús de Aragón no duda en alterar la historia en favor del interés de la aventura.

El autor retomó el falso origen templario de Casarás, ya recogido por Fagoaga y Muñico $(1845,210)-y$, a través de ellos, por Madoz $(1847,203)-$, para, junto a otros locales señalados por Espinar (2010, 1-2), vincularlo a la leyenda de los amantes de la Fuenfría, puesto que «nunca los templarios pudieron coincidir con la corte en Valsaín pues el primer monarca que acudió a esos parajes a cazar fue Enrique III, más de sesenta años después de la desaparición de la orden, y el primer palacio no se edificó hasta Enrique IV. Y menos con "Casarás", edificado en 1566» (Monterrubio 2013, 6), por una recomendación que Felipe II recibió de su consejero, Francisco Eraso.

Es posible que Jesús de Aragón se remitiera a la Espasa-Calpe para incluir algunos detalles históricos, pero si lo hizo fue muy a la ligera. Por ejemplo, sigue la lista de la enciclopedia universal en cuanto a los fundadores del Temple («Go- 
dofredo Roval, Godofredo Bisol, Payens de Montdidier, Archembaud de Saint-Aignan, Andrés de Montbard y Gondemar»), pero se salta a Godofredo de Saint-Omer, mencionado junto a Hugues de Payens más arriba en la entrada, y nos ofrece una curiosa lista: «Entonces, seis de sus amigos, escogidos entre los más ilustres de aquella esforzada milicia, que fueron Godofredo de Roval, el caballero Bisol, Payens de Mondidier, Archembaud de SaintAignan, Andrés de Montbard y Gomenar y Hugo de Champagne, juraron ante el rey de Jerusalén sus sagrados votos...» (78). O no se da cuenta de que le salen siete caballeros donde ha dicho que eran seis o, mejor, parece que interpreta que Andrés de Montbard y Gomenar (o Gondemaro, Gundemar) como un solo caballero (de ahí las dos conjunciones copulativas), por lo que en la lista incluye a Hugues de Champagne entre sus fundadores, algo que también hace la enciclopedia y que es un error histórico, puesto que el conde de Champagne, que viajó por primera vez a Oriente en 1104, solo regresó en 1114, tras abandonar a su esposa, para ingresar en la Orden en 1125 (Nicholson 2006, 37). También afirma la enciclopedia (729) que Hugues de Payens regresó en 1129 a Oriente, mientras que De Aragón nos lo dibuja en España: «notable caballero normando que visitó España por el año 1129, reclutando soldados para la gran cruzada» (77).

La cronología de La sombra es, insistimos, una pátina de antigüedad imprecisa, solo «medieval», por lo que nos limitaremos únicamente a señalar algunas particularidades. Se repite que son acontecimientos que tuvieron lugar ocho siglos antes $(26,42,57,58,60,129,133,151,174,190,191,197,198)$; otras veces, siete siglos $(55,76)$ u ochocientos años (190), y en ningún caso las cuentas salen. Pocas son las referencias concretas y las fechas que nos da Jesús de Aragón: se dice que Marignac llegó a Valsaín con apenas cuarenta años (80), aproximadamente cuando corría el año 1290. Imposible resulta, por tanto, que María de Molina estuviera encinta de la infanta Isabel en aquel período (91) porque la futura esposa de Juan III de Bretaña nació en 1283, ni Marignac pudo abandonar Acre, residir villanamente en Francia y cumplir un encargo del maestre Jacques de Molay cuando se inicia la persecución contra el Temple porque eso no sucedería hasta 1307. Del mismo modo, se afirma que el último propietario del castillo de Aspromonte era «en el siglo XIII, un hombre duro, de corazón empedernido, a quien las gentes de Reggio suponían en trato directo con el diablo, [que] partió con Hugo de Payens para las cruzadas» (57), algo que se repite después al referirse a «aquel tirano de corazón empedernido que partió hacía ocho siglos con Hugo de Payens a la conquista de los Santos Lugares» (58). La mención a Hugo de Payens debe entenderse como algo más simbólico que historicista, en tanto que el noble francés, en su calidad de miembro fundador y primer maestre de la Orden del Temple, había de ser una referencia conocida, solo equiparable a la de Jacques de Molay, el último de los maestres. Mal podía Hugo de Payens, muerto en 1136, partir a ningún lugar en el siglo XIII. Tampoco estuvo en España para fundar ningún monasterio, a pesar de que lo describa como «notable caballero normando que visitó 
España por el año 1129, reclutando soldados para la gran cruzada» (77). Hugo de Payens, para publicitar la nueva Orden, viajó a Escocia, Inglaterra y Francia: Champagne, Anjou, Maine, Poitou, Normandía, Inglaterra, Escocia, Flandes y el valle del Ródano (Frale 2008, 40): le tuvo que confiar a Raimundo Bernard, nuevo templario, la Península Ibérica (Demurger 2006).

Se dice, asimismo, que «Casarás fue fundado en 1150, en que algunos de aquellos héroes arrojados por Saladino vinieron buscar refugio en el recogimiento y en la paz de distintos sitios de las montañas hispánicas» (79-80): difícilmente podía Saladino, que apenas contaba con doce años de edad en 1150 , expulsar a nadie. Y es curioso que relate dos veces el altruista comportamiento de los templarios tras la caída de Jerusalén (78 y 94): pero si se narra que la ciudad santa cayó frente a Saladino, Marignac no podía haber combatido, porque tuvo lugar durante el año 1187. Si se refiere a la breve ocupación merced a los tratos de Federico II, ni Saladino ni Marignac podían estar presentes, dado que aconteció en 1244. Por su parte, Jacques de Molay sustituyó a Teobaldo Gaudin, muerto en abril de 1292, y sí era maestre general de la Orden. Pero si Marignac viene a España tras los arrestos de 1307, nunca pudo encontrarse con el rey Sancho IV, que murió en 1295. El proceso en Castilla contra los templarios se produjo durante el reinado de Fernando IV, también «emplazado», como Felipe IV de Francia ${ }^{22}$. En otros momentos, el autor confunde los nombres: afirma que «La reina, entonces encinta de la princesa doña Isabel, que fue luego esposa de don Juan II de Aragón ...» (91), cuando en realidad será la esposa de Jaime II, o los manipula interesadamente, como notan Fioraso y Fioraso $(2007,236)$ al respecto de Reggio Calabria.

En cuanto a sus fuentes literarias, es posible que conociera la obra de Enrique Gil, pero dudosamente se inspiraría en ella para sus templarios. Hugo de Marignac tiene más de los templarios scottianos y europeos que de los castos templarios españoles de la novela histórica decimonónica ${ }^{23}$. Si se busca una referencia, lo más acertado sería considerar que conocía la obra de Juan de Dios de Mora (1856-57), puesto que Marignac bien podría ser un alter ego del pérfido Matías Rafael Castiglioni. Ambos son, en fin, la causa de la caída en desgracia de la Orden, y sus crímenes parangonables. En ambas novelas ocupan un lugar destacado el tesoro de la Orden, el bafomet templario y la presencia de magos.

Los templarios que Jesús de Aragón presenta están bien arraigados en la tradición decimonónica española, en la que, a pesar de las evidentes simpatías que despertaba la Orden, se optaba por una visión prudente que no los exculpaba de faltas como la soberbia o la ambición desmesurada. En esta línea, se

${ }^{22}$ Curiosidad histórica aprovechada por la literatura templaria, como ocurre en la obra de Antonio Galera Gracia, (1999). El último secreto de los caballeros templarios. Murcia, KR (reeditada en 2005 por Styria, Barcelona, bajo el título de El último secreto templario).

${ }^{23}$ Sobre la Orden del Temple en la novela del siglo XIX, véanse Bergquist (1997) y Huertas Morales (2015, 128-137). 
afirma que la Orden «adulterando sus hermosos fines, se hizo rica y poderosa, cambiando con ello hasta la pureza de sus costumbres y nublando en la paz de las ciudades su magnífico historial» (79); «No se sabe hasta dónde hubiera llegado aquel poder casi sin límites y las costumbres libres y disolutas que la molicie y el lujo fueron introduciendo poco a poco en aquella orden ...» (79), y «Decíase que había comunidades que al contacto con el mundo habían abandonado por completo las leyes de la religión y de la moral católica para entregarse de lleno al servicio del demonio» (79), a la par que se recuerdan las acusaciones históricas que sufrieron: herejía, por pisotear y escupir sobre la cruz, sodomía y, el núcleo de la narración, la idolatría: «Decíase también que adoraban al diablo en figura de una cabeza humana llamada Bafonet y que este mortal enemigo del hombre se les aparecía frecuentemente en forma de gato negro en virtud de ciertas invocaciones mágicas que, al par que otros conjuros, conocían» (79).

La novela no exculpa al rey Felipe el Hermoso, recordándonos su odio a la Orden (59) y su codicia $(82,89)$, así como los intereses políticos de otros monarcas (Sancho IV, que es presionado), pero explicando que sí hubo templarios malvados, el grupo de Marignac, capaz de apartar de la virtud incluso a unos cuantos caballeros españoles. Hugo de Marignac, en la línea de Brian de Bois-Guilbert, Gutierre de Saldaña o Guillelmo Anglesola es un templario corroído por la ambición, la soberbia y el orgullo («Hugo de Marignac no ha reconocido jamás obstáculos para sus empresas. No ha temido ni la ira del rey, aunque ese rey, como Felipe de Francia, amenazara su soberbia con la hoguera» [99]), pero del valor de los templarios da buena cuenta el doble relato (78 y 94) de su noble acción tras la caída de Jerusalén y la espada de Bisol, que arriesga su vida defendiendo al caballero. De nuevo nos encontramos ante un templario secuestrador de doncellas (fruto de sus desmanes pecaminosos o de su ayuda, más o menos desinteresada, será un papel ampliamente revisitado por los templarios literarios del siglo XIX) que, como Bois-Guilbert a Rebeca, pretende seducir a su dama con promesas de oro y poder (99). Es posible, además, que Jesús de Aragón conociera la Regla templaria, seguramente a través de Scott, por los pecados que les atribuye, como el lujo en la vestimenta, que el escritor escocés también censura a Bois-Guilbert: «Contra todos los preceptos de la orden, aquel extraño monje usaba larga melena y vestía, en sus frecuentes viajes a Segovia, como el más apuesto doncel de la corte de Sancho IV» (80).

\section{EL TESORO TEMPLARIO}

La historia es sobradamente conocida: tras el concilio de Troyes y los viajes de promoción de los primeros templarios, la Orden, cuyos miembros habían hecho el voto de pobreza, empieza a recibir numerosas donaciones, a gestionar sus propiedades y encomiendas y a establecer un sistema financiero entre Occidente y Oriente. Diferentes bulas (en 1139, Omne Datum Optimum, por Inocen- 
cio II; en 1144, Milites Templi, por Celestino II, y en 1145, Milites Dei, por Eugenio III) les permiten depender únicamente de la autoridad pontificia y gozar de privilegios y exenciones que, a la vez que explican la pujanza de la más importante orden militar del medievo, le valen también todo tipo de críticas, entre las cuales destaca la de la avaricia: a los templarios solo les interesa el dinero.

Al otro lado de las acusaciones que propiciaron su caída se encontraba Felipe el Hermoso, siempre necesitado de dinero. Hoy los historiadores establecen matices, puesto que «A la luz de las fuentes históricas, la hipótesis parece demasiado simplista y poco realista, porque Felipe el Hermoso conocía perfectamente la magnitud de aquel patrimonio $\mathrm{y}$, por otra parte, las maniobras de la corona para la adquisición del Temple se venían desarrollando desde hacía años» (Frale 2008, 195). La ruina de los templarios fue probablemente consecuencia de la ira del rey ante la terquedad o la desobediencia imaginaria de sus vasallos (Partner 1987, 97) o un intento de reducir los privilegios de las órdenes militares, que suponían un obstáculo para el desarrollo de los monarquías centralizadas y el estado moderno (Demurger 2006), pero sin que se descarte el interés económico: Felipe IV preguntó a la Universidad de París sobre cómo debía de procederse con los bienes de la Orden, y poco después de las detenciones, el genovés Cristiano Spinola ya sugería que los intereses serían su dinero y unir y controlar ambas órdenes (Partner 1987, 76). Suspendida la Orden, el Hospital de San Juan se hizo cargo de las posesiones templarias (con la excepción de las que pasaron a la Orden de Montesa, en Valencia, y a la Orden de los Caballeros de Cristo, en Portugal), pero tuvieron que indemnizar a Felipe IV con doscientas mil libras.

El resto es mito. Y literatura. El tesoro templario, para algunos hallado en la mezquita de al-Aqsa que les otorgó Balduino II, ha sido emparentado con otras leyendas, como la de los cátaros, el Grial, la llegada a América y, en las últimas décadas, la del linaje de Jesucristo, y su búsqueda subyace en numerosas obras narrativas, organizadas según el esquema tradicional de las etapas, pesquisas y pruebas que los protagonistas deben superar para hacerse merecedores de él ${ }^{24}$.

${ }^{24} \mathrm{La}$ narrativa sobre los presuntos tesoros templarios daría para varios volúmenes. Véanse, solo como ejemplo, Asensi, Matilde (2000). Iacobus. Barcelona: Plaza \& Janés; Caballero, Abel (2001). La elipse templaria. Barcelona: Martínez Roca. Díaz Húder, Javier (2006). El renacer del Temple. Barcelona: Belacqua; Gutiérrez, Ángel y David Zurdo (2000). Síndonem, Barcelona: Robinbook; Martínez Fabado, Carlos (2009). El último albéitar templario. Valencia: Carena; Molist, Jorge (2004). El anillo: la herencia del último templario. Madrid: Martínez Roca; Navarro, Julia (2004). La hermandad de la Sábana Santa. Barcelona: Plaza \& Janés; Tristante, Jerónimo (2008). El tesoro de los nazareos. Barcelona: Roca; Wilcox, Nicholas (1996). La lápida templaria. Barcelona: Planeta; Wilcox, Nicholas (2000). Los falsos peregrinos. Trilogía templaria I. Barcelona: Planeta; Wilcox, Nicholas (2000). Las trompetas de Jericó. Trilogía templaria II. Barcelona: Planeta; Wilcox, Nicholas (2001). 
Existe, sin embargo, una temprana versión, originaria de las deposiciones del juicio a la Orden, del tesoro: el testimonio de Jean de Châlons, que aseguró que Gérard de Villiers, avisado de las detenciones, había huido con cincuenta caballos y se había embarcado al frente de una flota de dieciocho galeotes, mientras que Hugues de Châlons había marchado con todo el tesoro de Hugues de Pairaud, visitador de Francia ${ }^{25}$.

Esta será la versión retomada por Jesús de Aragón, pero añadiéndole, amén de un origen egipcio, la imprescindible maldición: Oriel, a quien Marignac conoció en Caldea (107), es descendiente de los edomitas, los guardianes encargados de su custodia por los faraones. Los primitivos tesoros proceden del tiempo de Cheos, faraón de la IV dinastía menfítica, y es infame por proceder de la explotación mediante tributos y de las guerras y pillaje de los faraones frente a los pueblos sometidos. Debía servir para los esclavos constructores de pirámides, pero los encargados se lo quedaban, hasta que un nuevo faraón lo recuperó y lo acrecentó con los de Cambises, destruida Caldea, y construyó una fortaleza en Djeziret Faraun para custodiarlos. Tesoro maldito por Ocías, pasó por las manos de la reina de Saba, que intentó con él conquistar, sin éxito, a Salomón; también por las de Cleopatra, que pretendía usarlo para hacer suyo a Marco Antonio, y por las de Zanobia, princesa de Palmira, hasta que Hugo de Payens se hizo con él, y de ahí la desgracia de los templarios: frente al poderío musulmán y frente a los propios reyes de la cristiandad. Jesús de Aragón le dará una nueva ubicación literaria en nuestro territorio, la Ventana del Diablo, de donde presuntamente desaparecerá robado por uno de los malsines contratados por el alemán, con la curiosidad de que, tras la Guerra Civil, y como ha sucedido con tantos otros buscadores de tesoros, la lectura de la novela excitó la imaginación de los lectores y hubo quien trató de hallarlo en la zona.

\section{LOS MAGOS Y EL BAFOMET}

Bafonet no es ningún nombre de persona, como fácilmente se echa de ver; Bafonet es una palabra oriental. El nombre de un ídolo abominable, tal vez el de un

La sangre de Dios. Trilogía templaria III. Barcelona: Planeta, 2001; Wilcox, Nicholas (2004). Los templarios y la mesa de Salomón, Madrid, Martínez Roca.

25 «Item dixit, quod potentes ordinis prescientes istam confusionem fugiunt et ipse obviavit fratri Girardo de Villariis ducenti quinquaginta equos, et audivit dici, quod intravit mare cum XVIII galeis, et frater Hugo de Cabilone fugiit cum toto thesauro fratris Hugonis de Peraudo. Interrogatus, quomodo potuit tandiu istud factum teneri secretum, respondit, quod nullus pro aliquis re erat ausus revelare, nisi papa et rex aperuissent viam, quia, si sciretur in ordine, quod aliquia loqueretur, statim fuisset mortuus» (Finke 1907, II: 339). Cerrini $(2012,142-143)$ da cuenta de la aparición de un pequeño cofre con monedas de oro y de plata, nada que ver con el legendario tesoro escamoteado a las tropas reales. 
demonio. Su recuerdo va íntimamente unido a una historia espantos de crímenes y de tragedias que allá en la Edad Media logró trastornar a la cristiandad entera, porque sirvió de estandarte a unos cuantos hombres desalmados y viciosos que, a causa de sus abominaciones, consiguieron envilecer a una de las milicias más sublimes que creó la cristiandad de todos los tiempos, la invicta y aguerrida Orden de los Templarios. Ahora que saben esto, les diré también que el tétrico edificio de Casarás, construido en la cumbre de la Ventana del Diablo, no es otra cosa que un antiguo monasterio de templarios (31).

Así describe don Andrés el bafomet en La sombra. Es, de hecho, el distintivo de Hugo de Marignac, que no lleva en su capa la preceptiva cruz patada de los templarios, privilegio concedido en 1147 por el papa Eugenio III $^{26}$, sino una cabeza humana bordada en rojo ${ }^{27}$. De los diferentes cargos imputados contra los templarios, acusaciones que remitían en la mente del hombre medieval hacia otros procesos que conocían bien y que temían, los de mayor gravedad se centraban en la herejía, apostasía, la sodomía y la idolatría: los templarios adoraban a un gato-ídolo-cabeza que era en buena medida la responsable de los éxitos de la Orden ${ }^{28}$. Interrogados los monjes, sin embargo, lo que encontramos es una descripción del todo incoherente: cabeza de todos los materiales, a veces barbuda y cornuda, otras con dos $\operatorname{rostros}^{29}$. No se trata tampoco, como afirma don Andrés, de una palabra oriental, sino una deformación del nombre de Mahoma (Pernoud 2005, 187). Nicholson (2008, 297-299) apunta a que, quien elaboró las acusaciones, empleó la de la cabeza para confundir a los individuos ajenos a la Orden, ya que así lo hacían los hospitalarios; los asociaba con los musulmanes, o más bien, con la imagen que de ellos tenían los cristianos, o los vinculaba a prácticas mágicas. En palabras de Barber (1999, 267).

El objetivo que perseguían los que acusaron al Temple de adorar ídolos, arrancándoles la confesión de que los principales objetos de veneración eran un gato

${ }^{26}$ Pero ya se nombra en la bulla Omne datum optimum, de 1139, por lo que su uso era anterior. No sabemos por qué Jesús de Aragón luego la presenta con forma patriarcal y con cinco flores de lis (190).

${ }^{27}$ La cabeza bordada es descrita de forma similar también en 87, 143, 159, 196.

28 Tomo la traducción del apéndice de Barber (1999, 365-372) y señalo aquí los que nos interesan: Ítem, que adoraban a un gato, [el cual] a veces se les aparecía durante las asambleas. Ítem, que en cada provincia había ídolos, a saber, cabezas, algunas con tres caras, otras con una, y otras era una calavera humana. Ítem, que adoraban a esos ídolos o a este ídolo, y especialmente durante los grandes capítulos y asambleas. Ítem, que decían que esa cabeza podía salvarlos. Ítem, que [podía] hacerlos ricos. Ítem, que les dio toda la riqueza de la Orden. Ítem, que hizo que los árboles florecieran. Ítem, que rodeaban o tocaban cada cabeza de los citados ídolos con pequeños cordones, que luego se ceñían alrededor del cuerpo cerca de la camisa o de la carne.

${ }_{29}$ Gaucerandus de Montepesato decía que el ídolo «esse factam in figuram baffometi», mientras que Raymundus Rubei corroboraba la «figura baffometi», y que la lo adoraban «osculando sibi pedes, dicens Yalla, verbum Sarracenorum» (Finke 1907, 323). 
y una cabeza mágica, era explotar ciertas creencias populares fuertemente arraigadas. En líneas generales, estaban infiltrando el mensaje de que la Orden había sido corrompida por el Islam, recreando la idea, rechazada desde mucho tiempo atrás por la gente culta, de que los musulmanes practicaban la idolatría. Más en concreto, parecía que intentaban explotar la opinión asentada en la época de que el gato era la encarnación del demonio.

Reinach (1911) ya observó que un grupo de las confesiones templarias estarían emparentadas con una versión oriental de la leyenda de Perseo y Medusa, mientras que si atendemos a los registros en las propiedades de la Orden, la única «cabeza» hallada, inventariada como Caput LVIII, parece corresponder a un relicario. Hoy los principales historiadores de la Orden creen que podría tratarse tanto de la cabeza de Santa Eufemia como la de santa Úrsula y sus once mil vírgenes, culto difundido ampliamente durante la Edad Media (Nicholson 2006), el relicario del propio Hugues de Payens (Cerrini 2012, 89, Barber 1999) o la Síndone (Frale 2009) ${ }^{30}$.

En cuanto a la magia, vale la pena resaltar que los templarios, en su mayoría, eran gente inculta, desconocedores del latín ${ }^{31}$, más soldados que eruditos, de cuyas manos nos han llegado pocos textos, como se desprende de las declaraciones del proceso, hasta el punto de que quizá uno de los factores que contribuyó a su caída fuera la desconfianza hacia la cultura (Nicholson 2006, 13, 211; Partner 1987, 29-30) $)^{32}$. De hecho:

No existe prueba alguna de que los templarios poseyeran conocimientos de ciencias, y por supuesto tampoco de magia: la magia medieval era una ciencia sumamente culta, escrita y ejecutada en latín, mientras que los templarios eran en general individuos notablemente incultos (según parece, esta característica se debía a una política deliberada, pues se consideraba que los hermanos cultos podían llegar a resultar problemáticos) (Nicholson 2006, 24).

${ }^{30}$ La custodia de la sindone por parte de los templarios, defendida por Frale (2009) ha levantado tanto interés en medios de prensa y literatura divulgativa como voces críticas entre otros especialistas. Véase, por ejemplo, una de las reseñas a su ensayo: Vallerani (2009). De hecho, muchos historiadores se muestran escépticos no solo frente a la autenticidad histórica y la antigüedad de la sábana conservada en Turín como aquella que cubrió los restos mortales de Jesucristo, sino también frente a la presunta posesión o custodia por parte de los templarios, pues no hay pruebas de su existencia antes de la segunda mitad del siglo XIV. Véase Nicolotti 2001.

${ }^{31}$ En el siglo XVIII, Henri Grégorie les atribuyó un alfabeto secreto y en el siglo XIX el historiador y editor de la Regla templaria, Charles Hippolyte Maillard, dijo haber reconocido algunas letras en el manuscrito conservado en París, pero Cerrini $(2012,49-51)$ demuestra que es una fórmula popular empleada para la curación de los caballos. Sobre este uso de fórmulas populares, véase Kieckhefer (1992).

${ }^{32}$ Difiere Cerrini $(2012,159)$, para quien «I templari erano infatti uomini religiosi in contatto fin dalle origini con i migliori intellettuali del tempo ed essi stessi uomini di cultura», con una pequeña parte de responsabilidad en el renacimiento cultural del siglo XII. 
Por otra parte, la acusación de prácticas mágicas no era tanto explícita sino por asociación, y solo en el sur de Francia, donde la Inquisición estaba arraigada «encontramos testimonios de culpas notablemente vinculadas a la brujería (aquelarres y orgías colectivas), sin duda más graves que las acusaciones expresas de Felipe el Hermoso en su denuncia, que no contenía referencia alguna al satanismo y se limitaba a mencionar un ignoto ídolo barbudo; se disparó a ciegas sobre los imputados recurriendo a lo más abominable del imaginario colectivo» (Frale 2008, 259), en un intento, si se siguen las sugerentes hipótesis de Frale (2014), de derivar el pecado desde la homosexualidad hasta las orgías rituales. Sus contemporáneos no hicieron demasiado caso de la acusación de magia sino para probar su culpabilidad (Nicholson 2006, 335), y aunque no se olvidó durante el Renacimiento, la vinculación del Temple a las prácticas mágicas tomó fuerza de la mano de la masonería alemana en el XVIII, siglo de las luces, pero también de la literatura gótica: «El mito de los templarios fue en parte intento literario al gusto gótico y en parte el fruto de la experiencia religiosa teosófica. Nacido en el mismo ambiente dieciochesco que había producido el cuento gótico, contenía la mayoría de las emociones mágicas y sexuales que apreciaban los narradores góticos» (Partner 1987, 168). Johann August Starck fue el primero en fijarse de nuevo en el bafomet y afirmar que la magia del ídolo podía retomarse, mientras que Friederich Nicolai más adelante conjeturaba que la palabra era un compuesto de dos términos griegos que significaban 'color' (o, por extensión, ‘bautismo') y ‘espíritu' (Partner 1987, 132-133 y 150), emparentando templarios con gnósticos. Joseph von Hammer-Purgstall se irguió figura central de este proceso: queriendo desacreditar a los masones, afirmó que los templarios eran gnósticos y la cabeza adorada por los templarios era el bafomet gnóstico ${ }^{33}$. Desde entonces, el bafomet no ha dejado de suscitar todo tipo de aproximaciones esotéricas.

Carrère no era una excepción del gusto por el ocultismo, esoterismo y teosofismo del primer tercio del siglo XX, por lo que según Labrador y Sánchez (2002, 495), Jesús de Aragón podría haberse inspirado en La Casa de la Cruz (1924), en la que el espectro del padre Calatrava relata los desmanes de Álvaro de Carvajal y Pietro Exili y cómo se desarrolló la misa diabólica con la que el brujo pretendía descubrir el maleficio que se ceñía sobre Carlos II: «En el altar había un crucifijo invertido, y al encenderse las luminarias vi, con espanto inaudito, que sobre la figura del Salvador había un monstruo. Era el Bafomet de los templarios, el macho cabrío, con una cruz entre los cuernos, con un cuerpo de varón y pechos de mujer» (50), imagen también presente en La to-

33 Raynouard, que gozaría de notable fama en España, criticó tempranamente la obra de Purgstall en dos trabajos marzo y abril de 1819 (Journal des savans, pp. 152-161 y 221229, respectivamente), y Juan Cortada también se hizo eco. Véase Cortada, Juan (1840). El templario y la villana. Barcelona: Imprenta de Brusi, vol. I, pp. 217-218 (nota 3). 
$r r e^{34}$. Se impone matizar, sin embargo, que lo que Labrador y Sánchez (495) suponen una inexactitud en La sombra - «atribuir a Bafonet (pequeña cabeza humana de simbología gnóstica) la condición de potencia infernal» $\mathrm{y}$, tanto a Carrère como a Jesús de Aragón, un intento de «satanizarlo» (496)-, no es tal: bafomet templario ya estaba bastante satanizado. El propio Raoul de Gizi, en sus declaraciones, atribuía una forma diabólica a la cabeza templaria ${ }^{35}$, y aunque en ambas ceremonias aparezca un gato negro (de ojos dorados, en $\mathrm{La}$ sombra, de pupilas de oro, en La torre), creemos que Jesús de Aragón se basa en la tradición que asociaba al bafomet con el demonio, mientras que la imagen que nos da Carrère del ídolo templario es, sin embargo, muy concreta: la popularizada por el famoso ocultista Alphonse Louis Constant (Éliphas Lévi), para quienes «Los gnósticos hacían ígneo el cuerpo del Espíritu Santo, y a él era a quien adoraban en los sitios secretos del Sabbat o del templo, bajo la geroglífica figura de Bahpmet o del macho cabrío de Androgino de Mendes» (1991, 12).

En la literatura española, Juan Pérez de Montalbán ya se refería a Los templarios como hechiceros e idólatras de una terrible figura: "Que son los más hechizeros, / y que tienen un cadáver / con dos carbuncos por ojos, / que pone horror el miralle, / a quien bárbaros adoran / con ceremonias infames» (2006, vv. 2144-2149), mientras que Enrique Gil presentaba las acusaciones de brujería como hablilla del vulgo o invención de los malvados interesados (Ribao Pereira 2014, 156-157), seguramente como respuesta a los crímenes que Scott vertía contra la Orden en The Talisman.

La primera mención explícita al bafomet templario que tenemos localizada en una novela histórica española se encuentra en Los templarios (1856-57), de Juan de Dios de Mora $^{36}$, que lo presenta como

34 «Sus temores fueron en aumento cuando a una señal del hierático jorobado se adelantaron dos enmascarados depositando junto al ataúd un braserillo de bronce figurando la cabeza de un macho cabrío, y en cuyas brasas quemó aromáticas esencias orientales» (210). «En el centro de la estancia se alza un braserillo de bronce, con la forma de la cabeza de un macho cabrío» (277).

35 «Interrogatus cujus figure est, dixit per juramentum suum quo dita est terribilis figure et aspectos quod videbatur sibi quod esset figura cujusdam demonis, dicendo gallice $d$ ' un maufé, et quod quocienscumque videbat ipsum tantus timor eum invadebat, quod vix poterat illud respicere nisi cum máximo timore et tremore». Nótese que emplea la palabra francesa «maufé», usada durante la Edad Media para designar al diablo.

${ }^{36}$ En la novela, Castiglioni encierra a doña Beatriz en la habitación del bafomet, que a decir de los distintos personajes es una figura con cabellera de sierpes «esculpidas en ciertos parages de las encomiendas» $(1856,69)$, «en todos los edificios de los Templarios se ven esculpidas estas figuras, las veneran tambien en secreto con estrañas ceremonias en una habitacion subterránea» (ibíd., 69), parece representar «una deidad misteriosa y siniestra» (ibíd., 69). Marigny le pregunta directamente a Jimeno «-¿Es verdad que adorais la figura de un gato y la espantosa cabeza de Bafomet?» (1857, 1037). En la legendaria filiación 
una figura espantosa con cabellera de sierpes y cabeza de dragon. Aquella cabeza era el bafomet que en la ideografía masónica de los Templarios significaba el mal principio ó el genio del mal. A la temblorosa luz de la lamparilla del italiano aquellas culebras parecian retorcerse, aquella boca de dragon parecia abrirse, y parecia que aquellos ojos feroces brillaban de júbilo y que las peladas calaveras con sus cavidades vacias lanzaban carcajadas llenas de un sarcasmo horrible $(1856,5-6)$.

A partir de ahí, tantas opciones como se quiera en la narrativa actual ${ }^{37}$, donde no faltan asociaciones con el mazdeísmo ${ }^{38}$. Jesús de Aragón conocía la relación entre los templarios y Egipto, y a pesar de sus ideas conservadoras no creemos que satanizara el mazdeísmo por beatería, puesto que bastante macabras son las imágenes que utiliza, sino más bien porque, dentro del género popular, las referencias a cualquier credo lejano debían tener resonancias siniestras para el lector de la época. De hecho, no compartimos aquello de que Jesús de Aragón «no diferencia entre los dos principios claves de la religión de Zoroastro» que Labrador y Sánchez $(2002,495)$ esgrimen para demostrar que no andaba muy sobrado de cultura religiosa: tanto en La torre como en $L a$ sombra las invocaciones a Ohrmazd y a Ahrimán -variantes del persa medio para Ahura Mazda y Angra Mainyu, responsables del bien y la vida y del mal y la muerte, respectivamente (Durán Velasco, 2013)-, aunque llevadas a cabo por malvados, parecen obedecer a una lógica: a Ohrmazd se lo invoca para devolverle la vida a Ercole (La torre) y a Marignac (La sombra), para que le retire la sensibilidad, y por tanto el dolor, a Basilio (La torre), o para conocer el futuro (La sombra), mientras que Ahrimán para llevar la muerte a Carlos de Mantua (La torre).

Simplemente, al novelista le interesaba sobre todo la aventura y las acciones en las que se veían envueltos los protagonistas: tan absurdo atribuirle intenciones historicistas como erudición en las diferentes religiones ${ }^{39}$. Sus tem-

entre masones y templarios ya había incidido Josep Marià Riera i Comas en su extensos Misterios de las sectas secretas, ó, el franc-mason proscrito, en diez volúmenes (1847-1850).

37 Para otras apariciones del Bafomet en la narrativa española o extranjera, véase, solo a modo de ejemplo, Barbet, Pierre (pseudónimo de Claude Avice) (1972). L'Empire du Bafomet. París: Fleuve Noir, donde el bafomet es un extraterrestre que pretende manipular a los templarios; Ruiz, Miguel (2008). El Papa Mago. Madrid: Martínez Roca, en la que se identifica el bafomet templario con una portentosa maquina creada por Silvestre II, con las claves para evitar el final de la humanidad en el segundo milenio; o Rua, Martin (2013). Le nove chiavi dell' antiquario. Roma: Newton Compton, donde el bafomet templario, creado por los magos caldeos, permite invocar el poder del Guardián del Umbral.

${ }^{38}$ Véase, por ejemplo, Ferrer, Chema (2008). Los talismanes del rey. Barcelona: Styria, reeditada precisamente como Ahriman. El secreto templario, en el año 2013.

39 Llaman la atención las variantes empleadas por Jesús de Aragón, por extrañas o minoritarias, especialmente las de «bafonet» por «bafomet»o «baphomet», «Arimanes» por «Ahriman», o «non nohis» en lugar de «non nobis». 
plarios son descritos como magos (133, 161, 162, 202, 203, 204), brujos (63, 189), nigromantes (59), hechiceros (60), quirománticos (147), en todo caso seres satánicos seguidores de Luzbel (147) y un mazdeísmo poco preciso -los rituales van acompañados de la recitación de los Vedas- y emparentado con una deidad, bafomet, que acabará revelándose como el mismo diablo en su forma tradicional de gato ${ }^{40}$.

Cuando Blanca rechaza a Marignac, el templario se escuda en su ciencia (100) y recurre a otro mago, Oriel, para rendirla: «Bien sabes tú que sí, pero sabes también que para conseguir lo que me pides es necesario cometer una monstruosidad horrible que satisfaga a Bafonet. Pero sea como tú quieres. Vuelve mañana por la noche y tráeme la víctima que es necesaria para la invocación que me propones» (111).

Como Ahrimán, Bafomet, aunque de potencias imprecisas, se yergue una fuerza diabólica. Así parece desprenderse de la despedida que le dedica un hermano lego a Marignac cuando parte raptar a Blanca (118). El mal templario se hace reconocer con ese nombre por sus compinches en el rapto (115), por él jura (125) y a él se encomienda, acosado por sus enemigos. Para encontrar el tesoro, a él debe hacerse la invocación, en un ritual que exige de víctimas humanas (153) y, según cuenta Gabriela, recurrir a él les permite también desentrañar el futuro (159).

Pero además de magos, los templarios de Jesús de Aragón son también criaturas sobrenaturales. El intento de resurrección de la La torre deja de ser farsa en La sombra y asistimos a la posvida o vida de ultratumba de Hugo de Marignac-Marqués de Aspromonte, quien aúna, si pensamos en Gautier, al Romuald que traiciona los votos y a la amante y muerta Clarimonde, además de tratarse de un espectro al frente de un ejército de autómatas o zombis:

-Lo mismo -replicó ella-. Son cadáveres animados por no sé qué mágico poder de ese hombre. Lo aseguro porque yo misma he asistido a la exhumación de algunas de esas momias vivientes y he presenciado la extraña ceremonia de ponerlos en movimiento. Eso, claro está, sin que me vieran. Son verdaderas máquinas humanas, cuerpos sin voluntad y hasta sin alma racional me atrevería a decir, que se mueven al influjo de una voluntad que les transmite su mecánica existencia. Estoy segura de que solamente parte de las facultades mentales de esas sombras están despiertas; las demás permanecen muertas: muerta la voluntad, muerta la memoria, muerto el entendimiento en todo aquello que no sea el movimiento casi mecánico de ordenar las escasas ideas para obedecer el mandato de esa voluntad imperiosa. No tienen más parte viva en su cerebro que unas cuantas celdillas de sus propiedades pensantes, receptoras de las influencias de ese mago. Así, comprenderá usted que no sientan necesidad de descansar ni de dormir (157).

40 Para añadir más elementos a este catálogo del mal, Von Kunzel afirma que Graciela fue sacrificada en honor a Azrael (133). 
La novela de Jesús de Aragón, es por tanto, pionera en el trato sobrenatural de los caballeros templarios, línea ampliamente explotada en la narrativa contemporánea, y quizá una de las primeras de la novela moderna. En el siglo XIX, solo con reservas podemos aceptar esta asociación. En la literatura española, Bécquer, influido por Enrique Gil (Picoche 1986, 52-53), y Blasco Ibáñez habían iniciado esta línea sobrenatural, pero en sus leyendas (nota 15), mientras que, de entre los autores extranjeros, George MacDonald publicó en 1858 un Faerie Romance en el parece remitirse a la Orden: el protagonista se encuentra entre «tres filas de hombres ataviados con túnicas blancas, con aire solemne y silencioso y una espada en el costado, aunque en todo lo demás tenían un aspecto más religioso que castrense» $(2014,259)^{41}$. En cuanto a los contemporáneos de Jesús de Aragón, únicamente conocemos el relato de Seabury Quinn, maestro del pulp: una de las aventuras del detective Jules de Grandin (Weird Tales, diciembre de 1928) aparece protagonizada también por «un alma sensible, una psíquica» $(2017,268)$ y retoma los presuntos asesinatos rituales que la orden realizaba en Chipre, según Partner (1987, 104-106) incorporados a las Grandes Chroniques de Francia y a la Chronique de Saboye de Paradin a través de Psellos ${ }^{42}$.

Sin embargo, lo que nos ofrece la narrativa fantástica sobre el Temple en las últimas décadas es una lectura actualizada en clave fantástica de las palabras de San Bernardo ${ }^{43}$. Si para el valedor del Temple la milicia terrenal era malicia y los templarios «malicidas» $(2005,45)$, porque luchan contra el pecado y el pecador ${ }^{44}$, la literatura de corte sobrenatural nos los dibuja como brazos armados de la divinidad, en una lucha constante contra las fuerzas del mal (Huertas Morales 2015, 172-176). De ahí también la originalidad de la obra de Jesús de Aragón, que convierte a los conmilitones Christi en malignos espectros que vagan por el tiempo.

${ }^{41}$ Nicholson $(2006,337)$ : «En ningún momento se utiliza la palabra "templario", pero los paralelismos con los hermanos del Temple y las acusaciones lanzadas contra ellos son evidentes: caballeros vestidos de blanco que además son religiosos, actúan en un templo, y adoran un ídolo que acarrea la muerte de los jóvenes iniciados. Al comienzo de la novela vemos al protagonista leyendo un relato acerca de un joven nigromante que posee una copia de las obras de magia de Cornelio Agripa».

${ }^{42}$ Los sacrificios rituales y las orgías, tan de gusto gótico, ya figuraban en la novela de Lamothe-Langon, Étienne-Léon de (1818). Les mystères de la Tour de Saint-Jean ou les Chevaliers du Temple, atribuida a M. G. Lewis, traducida el español, sin el nombre del autor y con la única indicación de «novela traducida del francés», como Los misterios de la torre de San Juan o Los caballeros templarios. Madrid: Imprenta de don José María Alonso, 1849 y Sevilla: Imprenta de Gómez, 1851.

${ }_{43}$ Con pocas excepciones, entre las que destaca la saga de Amando de Ossorio, sobre la que publicamos un trabajo con algunas lagunas, dado que por aquel entonces no conocíamos la novela de Jesús de Aragón. Véase Bosch Moreno y Huertas Morales (2016).

${ }^{44}$ La misma idea en la carta de Ugo Pecator (que podría ser Hugo de Payens o Hugo de San Víctor) y que anima a "state saldi e resístete al vostro avversario, al vostro leone e drago. Viene infatti come un leone per spezzarvi, viene come un drago per ingannarvi». Se encuentra traducida íntegra al italiano en Cerrini (2012, 119-124). 


\section{CONCLUSIONES}

Aunque su estructura presente incoherencias, seguramente debidas a su carácter de borrador, y la deuda con Emilio Carrère exceda la mera inspiración -como sucede con el personaje de Von Kunzel, uno de los mayores logros de la novela-, sigue siendo inapropiado soslayar los méritos de La sombra. Jesús de Aragón fue un hábil urdidor de tramas en las que la aventura primaba sobre el dato o el rigor histórico, y con La sombra fue capaz de recrear en clave gótica el paisaje segoviano de su infancia, fusionando tradiciones preexistentes (la fundación templaria de Casarás y la de los amantes de la Fuenfría) para el imaginario popular posterior y dando a las letras españolas la que consideramos como la primera novela en clave fantástica sobre el Temple. El de Valsaín lo hizo, además, a través de la reelaboración de dos de las leyendas más revisitadas por la literatura sobre la Orden: la de su tesoro y la de la adoración a bafomet, caracterizando a los templarios como malvados personajes de ultratumba, imagen que contrasta con la definida por la novela en los siglos XX y XXI. El resto -la hibridación temporal, la presencia de la crónica medieval, la inclusión de lo sobrenatural, etc.- es tan del gusto del lector actual que, no tenemos duda alguna, le granjeará nuevas y más detalladas aproximaciones.

\section{FUENTES}

Aragón, Jesús de. 2013. La sombra blanca de Casarás. Prólogo de Héctor Monterrubio Santín. La Granja de San Ildefonso: Ícaro.

Carrère, Emilio. 1921. La conversión de Florestán. Madrid: Prensa Gráfica.

Carrère, Emilio. 1924. La casa de la cruz. Madrid: Sucesores de Rivadeneyra.

Carrère, Emilio. 2004. La calavera de Atahualpa y otros relatos. Prólogo de Jesús Palacios. Madrid: Valdemar.

Carrère, Emilio. 2010. El diablo de los ojos verdes y otros relatos. Prólogo de Luis Antonio de Villena. Madrid: Salto de Página.

Carrère, Emilio. 2015. La torre de los siete jorobados. Prólogo de Jesús Palacios. Madrid: Valdemar.

Claraval, Bernardo de. 2005. Elogio de la nueva milicia templaria. Madrid: Siruela.

Enciclopedia universal ilustrada europeo americana. 1928. vol. LX. Madrid: Espasa-Calpe. Espinar de Andrés, Pedro Emilio, ed. 2010. Jesús de Aragón. La sombra blanca de Casarás. Segovia: Ediciones Populares El Laberinto de La Granja.

León, Ricardo. 1942. Los caballeros de la cruz. Madrid: Librería General de Victoriano Suárez.

Lejárraga, Antonio. 1995. «Prólogo». En La sombra blanca de Casarás. Barcelona: Juventud. López Santos, Miriam, ed. 2010. Pascual Pérez y Rodríguez. La runa sangrienta o El panteón de Scianella. Madrid: Siruela.

MacDonald, George (1858) 2014. Fantastes. Girona: Atalanta.

Madoz, Pascual. 1947. Diccionario geográfico-estadistico-historico de España y sus posesiones de Ultramar. Tomo VIII. Madrid. Est. Tipográfico-Literario Universal. 
Molina Foix, Juan Antonio, ed. 2008. Matthew Gregory Lewis. El monje. Madrid: Cátedra. Pérez de Montalbán, Juan (1635) 2006. Los templarios. UC Santa Bárbara: eHumanista.

Pérez y Rodríguez, Pascual. 1831. La torre gótica o el espectro de Limberg. Valencia: Oficina de López.

Pérez y Rodríguez, Pascual. 1833. El hombre invisible ó Las ruinas de Munsterhall. Valencia: Imprenta de Cabrerizo.

Picoche, Jean-Louis, ed. 1986. El señor de Bembibre. Madrid: Castalia.

Uribe, Augusto. 1994a. «Prólogo». En 40.000 km a bordo del aeroplano «Fantasma». Barcelona: Juventud.

Uribe, Augusto. 1994b. «Prólogo». En La noche sobre la ciudad prohibida. Barcelona: Juventud.

\section{BIBLIOGRAFÍA CITADA}

Aguilar, Santiago. 2002. Edgar Neville: tres sainetes criminales. Madrid: Filmoteca Española.

Aldana Reyes, Xavier. 2017. Spanish Gothic.National Identity, Collaboration and Cultural Adaptation. Londres: Palgrave Gothic.

Almela, Margarita. 2006. «La novela histórica española en el siglo XIX». En Reflexiones sobre la novela histórica, ed. José Jurado Morales, 97-141. Cádiz: Fundación Fernando Quiñones - Universidad de Cádiz.

Álvarez Rodríguez, Román. 1998. «De la novela gótica a la novela histórica, 1760-1840». En Historia crítica de la novela inglesa, ed. y coord. José Antonio Álvarez Amorós, 65-106. Salamanca: Ediciones Colegio de España.

Ara Torralba, Juan Carlos. 1996. Del modernismo castizo. Fama y alcance de Ricardo León. Zaragoza: Prensas Universitarias de Zaragoza.

Barber, Malcolm. 1999. El juicio de los templarios. Madrid: Editorial Complutense.

Bergquist, Inés L. 1997. «Imágenes de los templarios del siglo de Oro al Romanticismo». Medievalismo 7: 151-184.

Boix, Armando. 2000. «Explorando maravillas: la novela fantástica en España antes de 1958». En La novela popular en España, 121-132. Madrid: Robel.

Bosch Moreno, María y Antonio Huertas Morales. 2016. "Caballeros de la oscuridad: la Orden del Temple en el cine de Amando de Ossorio». Romanica Silesiana 11 (2): 52-61.

Cansinos Assens, Rafael. 1985. La novela de un literato. 2. 1914-1923. Madrid: Alianza.

Cerrini, Simonetta. 2012. L'apocalisse dei Templari. Milano: Mondadori.

Charlo Ortiz-Repiso, Ramón. 2013. La novela popular en España. Sevilla: Secretariado de Publicaciones de la Universidad de Sevilla.

Claraval, Bernardo de. 2005. Elogio de la nueva milicia templaria. Barcelona: Siruela.

Demurger, Alain. 2006. Auge y caída de los templarios. Madrid: Martínez Roca.

Durán Velasco, José F. 2013. Tratado de demonología. Córdoba: Almuzara.

Eguizadu, Fernando y Jorge Tarancón. 2008. Del folletín al bolsilibro. 50 Años de novela popular española 1900-1950. Catálogo de la novela popular española (1900-1936). Guadalajara: Silente.

Enríquez de Salamanca, Cayetano. 1981. Por la sierra de Guadarrama. Las Rozas: Cayetano Enríquez.

Fagoaga, José de y Tomás Muñico. 1845. Descripcion de los reales sitios de San Ildefonso, Valsain y Riofrio. Segovia: Imprenta de D. Eduardo Baeza. 
Ferreras, Juan Ignacio. 1976. El triunfo del liberalismo y de la novela histórica. Madrid: Taurus.

Finke, Heinrich. 1907. Papsttum Und Untergang des Templerordens. II. Band: Quellen. Münster: Aschendorffsche Buchhandlung.

Fioraso, Roberto y Nazzareno Fioraso. 2007. «Jesús de Aragón "el Julio Verne español”». En Emilio Salgari e la grande tradizione del romanzo d'avventura, ed. Luisa Villa, 225238. Genova: ECIG.

Frale, Barbara. 2008. Los templarios. Madrid: Alianza.

Frale, Barbara. 2009. I Templari e la sindone di Cristo. Bologna: Il Mulino.

Frale, Barbara. 2014. Crimine di stato. La diffamazione dei templari. Firenze - Milano: Giunti.

Gómez de la Serna, Ramón. 1944. Doña Juana la Loca (Seis Novelas Superhistóricas). Buenos Aires: Clydoc.

Gregori, Alfons. 2017. «Narrativa 1930-1950». En Historia de lo fantástico en la cultura española contemporánea (1900-2015), ed. David Roas, 39-56. Madrid - Frankfurt am Main: Iberoamericana - Vervuert, pp. 39-56

Huertas Morales, Antonio. 2015. La Edad Media contemporánea. Estudio de la novela actual de tema medieval (1990-2012). Vigo: Academia del Hispanismo.

Kieckhefer, Richard. 1992. La magia en la Edad Media. Barcelona: Crítica.

Labrador Ben, Julia M. ${ }^{a}$ y Alberto Sánchez Álvarez-Insúa. 2002. "Génesis y autoría de La torre de los siete jorobados de Emilio Carrère». Revista de literatura LXIV, 128: 475503. https://doi.org/10.3989/revliteratura.2002.v64.i128.180

Labrador Ben, Julia M. ${ }^{a}$ y Alberto Sánchez Álvarez-Insúa. 2004. «Nuevas pruebas documentales acerca de la autoría de La torre de los siete jorobados de Emilio Carrère». Anuario del Instituto de Estudios Madrileños XLIV: 929-934.

Lara López, Alfredo. 2000. «La novela de aventuras». En La novela popular en España, 97-120. Madrid: Robel.

Lévi, Éliphas. 1991. Dogma y ritual de la alta magia. Barcelona: Editorial Humanitas.

López Santos, Miriam. 2010. La novela gótica en España: (1788-1833).Vigo: Academia del Hispanismo.

Mata, Carlos.1995. «Estructuras y técnicas narrativas de la novela histórica romántica española». En La novela histórica. Teoría y comentarios, ed. Kurt Spang, Ignacio Arellano y Carlos Mata, 113-151. Pamplona: Eunsa.

Méndez, Lenina M. 2002. «La torre de los siete jorobados: una obra a ocho manos». Espéculo 21.

Mora, Juan de Dios. 1856. Los templarios. Vol. I. Madrid: Imprenta de Manuel Álvarez.

Mora, Juan de Dios. 1857. Los templarios. Vol. II. Madrid: Imprenta de J. Casas y Díaz.

Nicolotti, Andrea. 2001. I templari e la Sindone: Storia di un falso. Roma: Salerno Editrice.

Nicholson, Helen. 2006. Los templarios. Una nueva historia. Barcelona: Crítica.

Partner, Peter. 1987. El asesinato de los magos. Barcelona: Martínez Roca.

Pernoud, Régine. 2005. Los templarios. Madrid: Siruela.

Quinn, Seabury. 2017. Aventuras completas de Jules de Grandin. Tomo II. Bilbao - Madrid: La Hermandad del Enmascarado.

Reinach, Salomon. 1911. «La tête magique des Templiers». Revue de l' Histoire des Religions LXIII: 25-39.

Ribao Pereira, Montserrat. 2014. «La visión literaria de los Caballeros Templarios en El Señor de Bembibre, de E. Gil y Carrasco». Revista de Literatura LXXVI 151: 151-170. https://doi.org/10.3989/revliteratura.2014.01.007

Ribera, Antonio. 1984. Galería de condenados. Barcelona: Planeta. 
Sainz Cidoncha, Carlos. 1976. Historia de la Ciencia Ficción en España. Madrid: Sala Editorial.

Todorov, Tzvetan. 2001. «Definición de lo fantástico». En Teorías de lo fantástico, intro. y comp. David Roas. Madrid: Arco/Libros.

Uribe, Augusto. 2000. «El coronel Ignotus y el capitán Sirius, los dos pioneros de la ciencia fícción en España». En La novela popular en España, ed. Fernando Martínez de la Hidalga, vol. 2, 33-67. Madrid: Robel.

Vallerani, Massimo. 2009. «I templari e la Sindone: 1' "ipotetica della falsità" e l'invenzione della storia». Historia Magistra 2: 10-17.

Vázquez de Parga, Salvador. 2000. Héroes y enamoradas. La novela popular española. Barcelona: Glénat.

Fecha de recepción: 02 noviembre de 2017

Fecha de aceptación: 25 de enero de 2018. 